\title{
Peculiarity of the mammal associations from the Upper Pleistocene (Dobrogea, Romania)
}

\author{
Alexandru Petculescu*, Emanoil Ştiucă \\ Institute of Speleology, Bucharest, Romania \\ Available online 4 September 2007
}

\begin{abstract}
Paleontological studies of the mammals from the Upper Pleistocene at Dobrogea are distinct in comparison with other mammal associations from Romania. The paleoenvironment from the last glacial cycle (Wurm) is reconstructed on the basis of the mammal cave fossils discovered in caves at Dobrogea. Research in karst deposits from the last glacial cycle is based on systematic surveying of the most important paleontological sites.
\end{abstract}

(C) 2007 Elsevier Ltd and INQUA. All rights reserved.

\section{Introduction}

Located between the Danube River and the Black Sea, the territory of Dobrogea is distinguished by many climatic and faunal peculiarities compared with other regions of southern Romania. Paleontological investigations, carried out since 1956 in the karst deposits located in the Jurassic limestones of central Dobrogea, revealed a rich mammal association.

The paleontological studies of the mammals from the Upper Pleistocene of the Dobrogea region reveal distinct particularity in comparison with other mammal associations from Romania (Burghele et al., 1995). The research in karst deposits from the last glacial cycle is based on systematic surveying of the most important paleontological sites, including La Adam Cave, Cheia Cave, Casian Cave and Gaura Vulpii Fissure (Fig. 1).

\section{Mammals}

The mammal remains, especially herbivores, were accumulated in caves by Upper and Middle Paleolithic hunters. These communities within caves are represented on different levels by pebble tools and bones.

\footnotetext{
${ }^{*}$ Corresponding author.

E-mail address: romanianspeleology@k.ro (A. Petculescu).
}

Caves, used as shelters, were used not only by primitive humans but also by the large carnivores such as cave bear (Ursus spelaeus) and cave hyena (Crocuta spelaea). In the absence of humans, the carnivores used these places for shelter, birth, and nurseries. Thus, La Adam cave, during the middle phases of the last glacial cycle, was used by the hyenas which brought numerous remains there (Samson and Rădulescu, 1959; Dumitrescu et al., 1963; Terzea, 1972). Thanks to this "artificial selection", the number of the bones is not significant, but the faunal association, generally speaking, is relatively well represented.

The small mammal remains are due to the existence, next to the entrance of the caves, of nests of carnivorous birds. The remains were accumulated in chronological positions and represent a mirror of the mammalian associations outside, especially for the small mammals.

\section{Faunas from the last glacial cycle from Dobrogea}

During the Upper Pleistocene, Dobrogea was characterized by a cold climate with a strong continental influence and warm periods (interstadials). Northern species including Mamuthus primigenius, Coelodonta antiquitatis, Rangifer tarandus, Alopex lagopus, Stenocranius gregalis and Microtus oeconomus are present, with steppe elements including bovids, Saiga tatarica, ecvids (Equus cf. transilvanicus, Equus spelaeus spp., Equus sp., Hydruntinus hydruntinus), Vulpes corsac, and small mammals (Allactaga, Lagurus and 


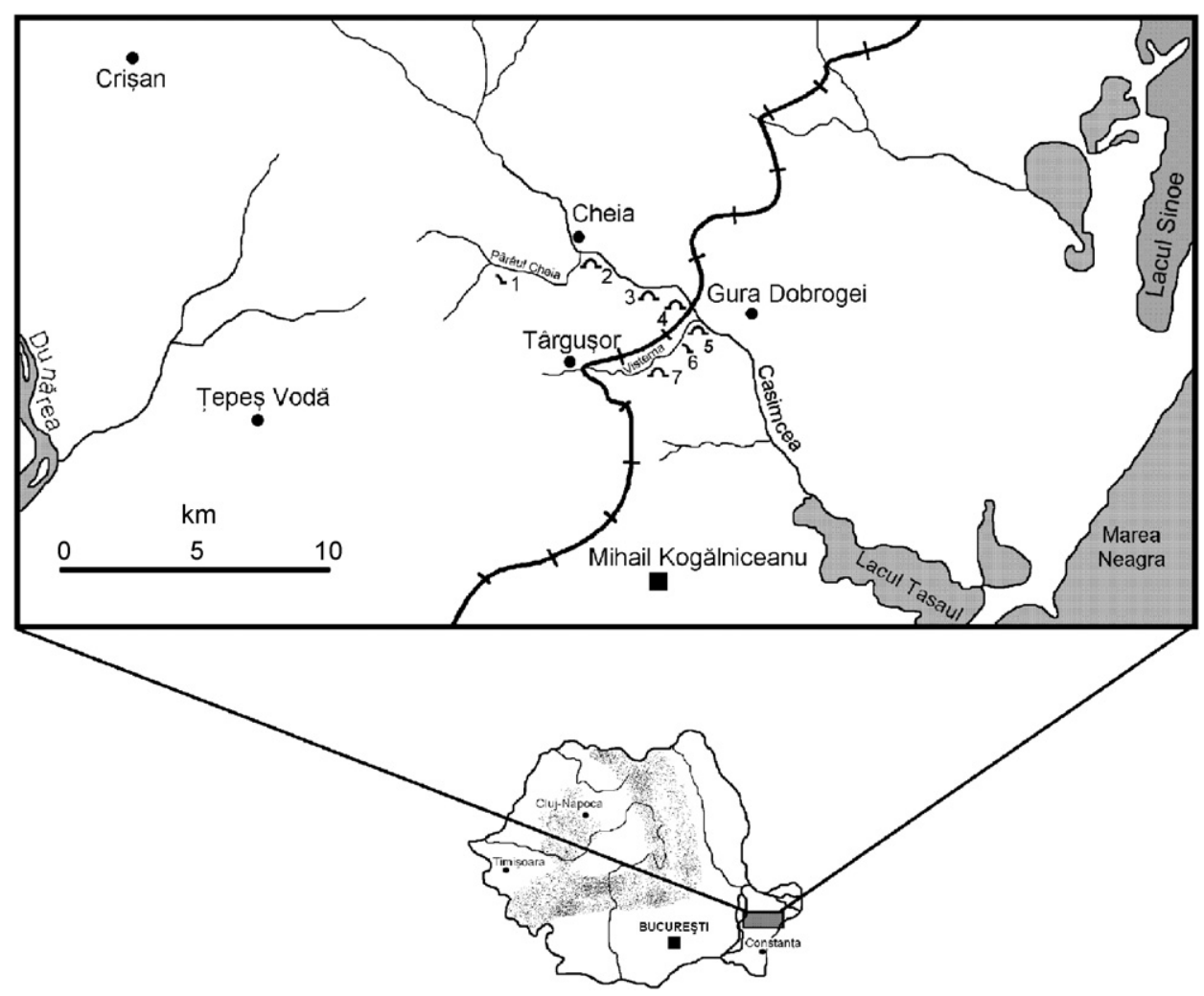

Fig. 1. Location map. (1) Bordeiul de Piatră rockshelter, (2) Cheia Cave, (3) Casian Cave, (4) Gaura Vulpii Cave, (5) Gura Dobrogei Cave, (6) Gura Dobrogei-4 rockshelter, (7) "La Adam" Cave.

Eolagurus genus) (Table 1). The yellow lemming (Eolagurus luteus), now living in central Asia, is represented in Dobrogea as the westernmost point of the range of a large group (Rădulescu and Samson, 1995). Other Nordic species, such as Lemmus and Dicrostonyx, are confined to northern Romania (Markova, 1982; Ştiucă et al., 2002).

The relative warming intervals in Dobrogea are represented by species such as Magaloceros giganteus and Cervus elaphus. In the first part of MIS 3 (local interstadials Adam I and Adam II), Bos primigenius was identified. In the second part of the same stage (Vistorna I) Martes sp. and Panthera pardus were found in La Adam Cave. MIS 2 is characterized by the existence of wild boar (Sus scrofa) associated with Megaloceros and Hydruntinus.

\section{Particularity of the small mammal associations}

The massive presence of the small mammal remains on different levels indicates some morphological and dimensional characteristics. Different subspecies can be separated statistically, especially the steppe lemmings and $S$. gregalis, as characteristic of distinct periods.

Lagurus lagurus dobrogicus and S. gregalis spp. from MIS 4 and the first part of MIS 3, are large. S. gregalis are very similar to the Siberian form.

Lagurus lagurus thracicus and Stenocranius gregalis anglicus from the last part of MIS 3 and MIS 2 are small. $S$. gregalis anglicus specimens are very close to the modern species from central Asia and the Ural Mountains. Some species are characteristic only for a clearly delimited period of time (e.g. Allocricetulus eversmanni, Scirtopoda telum).

\section{Chronology of the fossil deposits}

The position of the fossiliferous levels from the caves was correlated with the fossil soils from the entrance zone. A good example is the karstic deposits from La Adam cave, which grade into loess deposits and fossil soil near the entrance of the cave. This allows correlation with the well known loess stratigraphy of Dobrogea (Samson and Rădulescu, 1959; Conea, 1970; Samson, 1971). The thickness of the deposits from La Adam cave is around $15 \mathrm{~m}$. This section begin with the last part of the Riss, followed by a strong erosional period with red soil remains correlated with the Riss-Wurm interglacial, and a succession of layers with very rich small and large mammal remains, associated with Upper and Middle Paleolithic human industry (Leroi-Gourhan, 1969).

\section{Conclusions}

The similarity between faunal associations from Crimea and Dobrogea during the last glacial cycle occurred when the level of the Black Sea was $80-90 \mathrm{~m}$ below the present sea level, and Dobrogea was directly connected to the Crimea. These regions represent a bridge between the 
Table 1

Biochronology and chronostratigraphy of Dobrogea

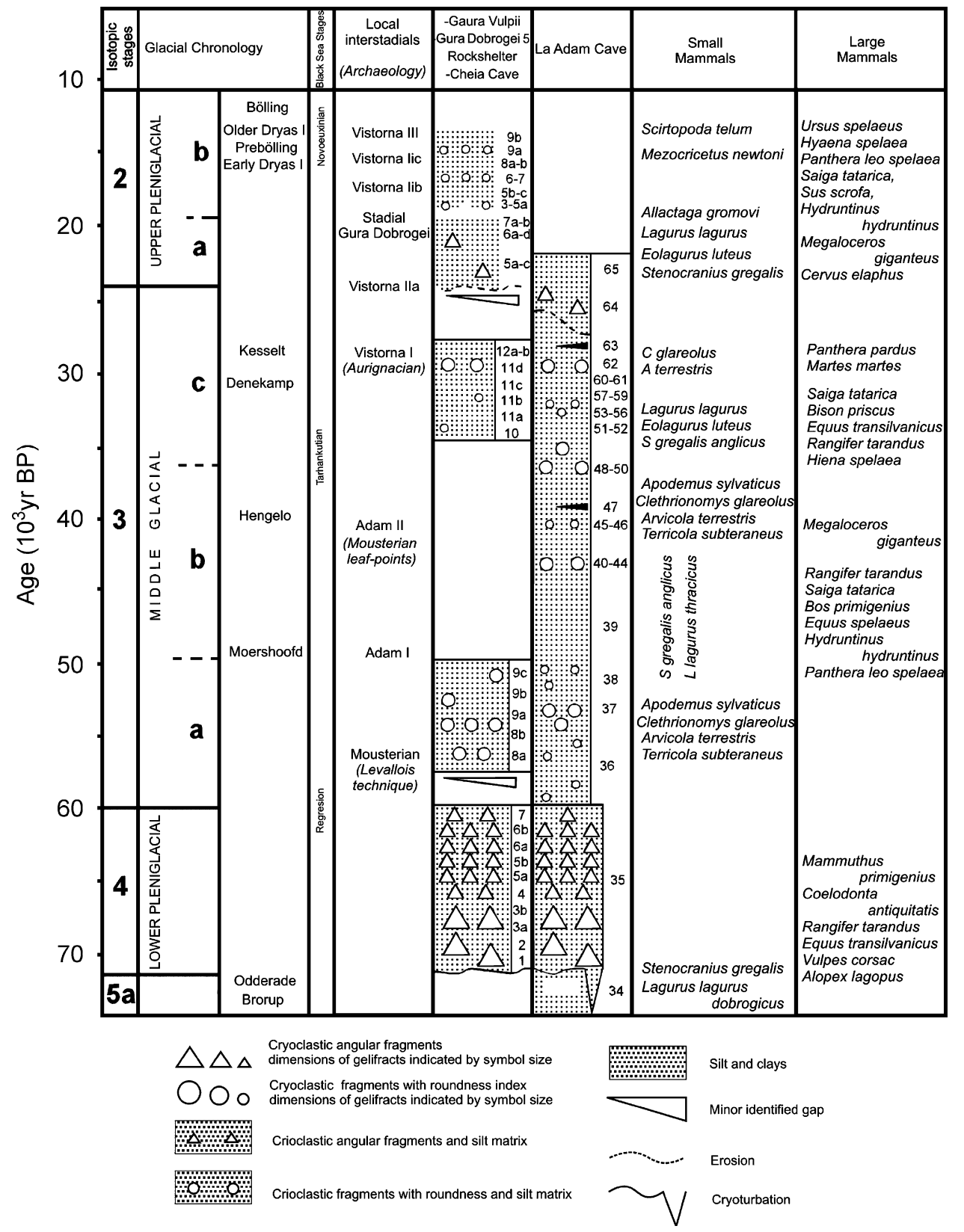

faunal associations from Eastern Europe and the Balkan Peninsula.

Evidence includes:

- dominance of $U$. spelaeus in the first stage of the last glacial cycle;

- presence of the steppe lemmings (Lagurus and Eolagurus) in both regions;

- presence of Scirtopoda telum in both regions;

- association between S. tatarica and Hydruntinus, common in Dobrogea and Crimea;

- presence of the carnivores $V$. corsac and A. lagopus in both regions;
- presence of Ovis orientalis remains in caves from Dobrogea and Crimea;

- Dobrogea was a very distinct region in the middle of the migration route between eastern Europe and central Asia and southeastern Europe in the last glacial cycle.

\section{References}

Burghele, A., Rădulescu, C., Samson, P.-M., Știucă, E., 1995. La première faune interglaciaire (Eemien ?) de micromammifères d'Olténie. Travaux de l'Institut de Spéologie Emile Racovitza 33, 101-106.

Conea, A., 1970. Quaternary formations from Dobrogea. Education Academy R. S. Romania, 234pp. 
Dumitrescu, M., Samson, P., Terzea, E., Rădulescu, C., Ghica, M., 1963. La Adam cave, Pleistocene site. Lucrarile Institutului de Speologie "Emil Racoviță I-II, 229-284.

Leroi-Gourhan, A., 1969. Dénomination des oscillations wurmiennes. Bulletin de l'AFEQ 4.

Markova, A.K., 1982. Pleistocene Rodents of the Russian Plain (in Russian). Nauka, Moscow, 184pp.

Rădulescu, C., Samson, P.-M., 1995. On some middle late pleiasocene rare small mammal elements from the Karst deposits of central Dobrogea (Romania). Theoretical and Applied Karstology 8, 163-173.

Samson, P., 1971. La stratigraphie du Quaternaire supérieur en Roumanie. VIIIe Congrès INQUA, Paris 1969. Études sur le Quaternaire dans le Monde.
Samson, P., Rădulescu, C., 1959. Beitrage zur Kenntnis der Chronologie de "Jungeren Losses" in der Dobrudscha. Eiszeitalter u. Gegenwart 10, 129-204.

Ştiucă, E., Petculescu, A., Arghir, R., 2002. Nouvelles donnees sur les faunes de microvertebres du Pleistocene superieur de Dobrogea, avec regard special sur la zone Movile (dep. de Constanta, Roumanie) Travaux de l'Institut de Spéologie "Emile Racovitza", Bucuresti, 41-42, pp. 111-121.

Terzea, E., 1972. Remarques sur la morphologie dentaire et la répartition de Microtus nivalis Martins (Rodentia, Mammalia) dans le Pléistocène de Roumanie. Travaux de l'Institut de Spéologie Emile Racovitza XI, 271-298. 